\title{
Application of RCM and FMEA Methodology to Improve Industrial Maintenance Management: A Case Study of Fibers for Mattresses
}

\author{
José Alfredo Carazo Luna* \\ Instituto de Ingeniería Industrial y Automotriz, Universidad Tecnológica de la Mixteca \\ Km 2.5, Carretera Huajuapan - Acatlima, 69000, Huajuapan de León, Oaxaca, México \\ Tel: 953-532-0399, ext670 E-mail: alfredo@mixteco.utm.mx \\ Moisés Manzano Herrera \\ Instituto de Ingeniería Industrial y Automotriz, Universidad Tecnológica de la Mixteca \\ Km 2.5, Carretera Huajuapan - Acatlima, 69000, Huajuapan de León, Oaxaca, México \\ Tel: 953-532-0399, ext 670 E-mail: mmanzano@mixteco.utm,mx \\ Esmeralda Pérez Cruz \\ Instituto de Ingeniería Industrial y Automotriz, Universidad Tecnológica de la Mixteca \\ Km 2.5, Carretera Huajuapan - Acatlima, 69000, Huajuapan de León, Oaxaca, México \\ Viridiana Vásquez Santos \\ Instituto de Ingeniería Industrial y Automotriz, Universidad Tecnológica de la Mixteca \\ Km 2.5, Carretera Huajuapan - Acatlima, 69000, Huajuapan de León, Oaxaca, México
}

\begin{abstract}
In industrial manufacturing, there are techniques that can identify certain risks in the processes that cause inconsistencies in the operation of equipment, hazards for the operator and waste. One of the supports of industrial engineering in the company are the Preventive Maintenance (PM) tasks that focus their efforts on analyzing the operation of critical devices that could degrade the quality of the products obtained. Companies that have an average system of attention to machinery and equipment perform corrective maintenance (CM) or preventive maintenance tasks that are not very successful, due to a deficient knowledge or training in repair, which generates high percentages of waste, low quality, and even reprocessing. Failure mode and effects analysis and reliabilitycentered maintenance are systematic tools based on team working which usually can be used for identify, prevent, eliminate or control the potential errors causes of failure in a system or process. In this paper, it is intend to reorganize preventive maintenance planning and obtain effective results with all the information and data available specifically on a machine dedicated to the transformation of a raw material to obtain fibers used in mattress filling. Keywords: Preventive Maintenance, Failure mode and effect analysis, reliability centered maintenance.
\end{abstract}

DOI: $10.7176 /$ IEL/12-1-04

Publication date: January $31^{\text {st }} 2022$

\section{Introduction}

The research indicates that the origins of what we know today as a mattress date back to prehistoric times. By lying on piles of leaves, straw and animal skins, early humans were able to sleep more comfortably and more soundly than on hard surfaces. As more people moved away from a nomadic, hunting lifestyle to an agrarian, sedentary lifestyle, primitive furniture, including the bed, began to develop. (López, 1989) The mattress, in most cultures, is the most used product; however, there are those who do not consider it as a key element in their lifestyles, neglecting its quality and adequate support (Toro E. , 2015). Until the twentieth century, they generally consisted of lumpy pads filled with horse hair, cotton, or rags. Mattresses are presently made of many materials, both natural and synthetic. The insulator consists of semi-rigid netting or wire mesh, and the cushioning layers can comprise a number of different materials including natural fiber, polyurethane foam, and polyester. (Pepper, 2018). In order to ensure that the products that make up the support and internal comfort of a mattress, we propose the development of an analysis of the machinery in the company Fibras de Colima S. A de C.V who is responsible for producing nonwoven fabrics (compressed) and has incidents in the production process such as production stoppages caused by the equipment, it is worth mentioning that the production process consists of production lines that are classified into line A, line B, Jumbo 1 and Jumbo 2. In the last decades, manufacturing industries had experienced an unprecedented degree of changes such as product specifications, process technologies, supplier attitudes and customer's requirements. This rapid changes environment had forced the manufacturers to enhance and improve effectively their performance by focusing on cost reduction, productivity levels increment, high quality products and prompt deliveries in order to satisfy customers. Because of the competitive market, 
improvement of maintenance strategy and scheduling has attracted manufacturers to adopt decision-making tool. (Ramli \& Nizam, 2012). The execution of this project is supported by two tactical level maintenance methodologies, which are RCM and FMEA. RCM, better known as Reliability Centered Maintenance, is used to determine what must be done so that any physical resource continues to operate normally, thus reducing downtime due to unforeseen failures; the objective of this methodology is to increase the reliability of the facility. (Rausand, 1998) The FMEA methodology refers to failure mode and effect analysis, which consists of the identification and classification of the effects, causes and elements of an occurrence in order to prevent failures. It should be added that, in order to carry out this project, first of all, the equipment with the highest number of failures in the production process was determined, and then the studies were focused on this equipment. Thus, the main objective was to evaluate this equipment by means of the aforementioned methodologies. (Command, 1983), (Afefy, 2010).

\subsection{Objetives of the study}

Develop an analysis of a company's fiber compactor equipment, applying RCM and FMEA methodologies, to reconfigure the preventive maintenance plan and integrate activities to improve operational performance.

\subsubsection{Specific Objetives}

- Determine the specific functions of the fiber compacting machine.

- Identify potential failures in the system in a normal operating environment.

- Reconfigure preventive maintenance actions to extend the time between failures.

\section{Description of the process}

The continuous production system for nonwoven fabric fibers is divided into five main areas, Jumbo Line 1 and Jumbo Line 2, which are in charge of producing the flock or raw material for the production lines, which are Line A, Line B and Line C. (Ivester \& y Neefus, 2012)

The process begins by sending bales of garment waste from the raw material warehouse to one of the Jumbo lines (Jumbo 1 and Jumbo 2), which are responsible for shredding the fabric waste, so that at the end of these lines a type of yarn known as flock is produced, which is compressed and stored until it is required. Once requested, it is deposited in one of the Production Lines (Line A, Line B and Line C), which are in charge of manufacturing fibers.

Jumbo 1and 2 Processes

The bales of clothing catalogued as "unusable" pass from the raw material warehouse to cutter 1 and 2 in series, then to the metal detector and subsequently, the pieces of fabric are directed to the silo and the milling machine to finally be deposited in the Jumbo machine, transforming them into lint. The material goes directly to Line A or to the condensers, which add cotton and then through pipes it is deposited in one of the lines. Finally it is transferred to a subdivision of the raw material area where it is compressed and stored for future production.

Line A

The process begins with the deposition of lint and cotton threads in the loaders, the material is directed by a conveyor belt to the horizontal opener and the firt opener, which open and distribute the compacted raw material. It then passes through a metal detector and then goes to the cyclone that captures and removes the dust. It then enters the Airlay Flexiloft equipment (Airlay Condenser, Loader, Airlay, Scale, Flexiloft) that processes the slurry. At the end of this process, it passes through lateral cutters that eliminate the excess. Then, it goes to the furnace, the calender and the cooling extractor. It reaches the side cutters and the guillotine, which are adjusted according to the shift measurements. Finally, they are picked up by the personnel who stack the material and send it to the finished product warehouse.

Line B

Raw material is deposited in the loader and opener, passing through the following stages: DOA system, punching machine, side cutters that eliminate the excess, advances to the impregnation rollers that were previously loaded with glue, thanks to the glue foaming system, oven and the calender. Finally, it collects in the receiver zone by the personnel who stack the product and when the number of pallets is completed, by means of a forklift they are transferred to the finished product area.

Line $\mathrm{C}$

The process of this line starts by feeding the loaders with flock and cotton threads, then the material is directed through a belt to the mixing piker that controls the length of the yarns. If there are traces of metal detected by a magnet, the material is diverts to the silo, otherwise the process continues to the opener.

The process continues in the Airlay Flexiloft system (condenser, loader, Airlay, scale and flexiloft). The material is then transferred to the side cutters, passing through the oven, cooling chamber, receiver, adjustment, cutting and guillotine according to specifications. Finally, it is collected, stacked and once the limit is reached, it is moved by forklift to the finished product warehouse. 


\section{Method}

During the operation phase of any equipment or system, the physical, mechanical and electrical resistance gradually deteriorates, leading to system failure. This failure of infrastructure or equipment due to component deterioration is a sign of the severity of the system. Today, more emphasis is being placed on the availability, reliability and safety of production plants. Therefore more and more companies have seen the need to replace their maintenance strategies with predictive maintenance (Dominic, 2021). One of the methodologies used in failure mode analysis is Reliability Centered Maintenance (RCM), and is defined as a process used to determine what must be done to keep any physical resource operating normally. The methodology is based on four objectives: preserve functions, identify failure methods that can disrupt functions, prioritize function needs, select only preventive and effective maintenance tasks. (Altaf, 2014) The application of the methodology follows a series of steps mentioned below.

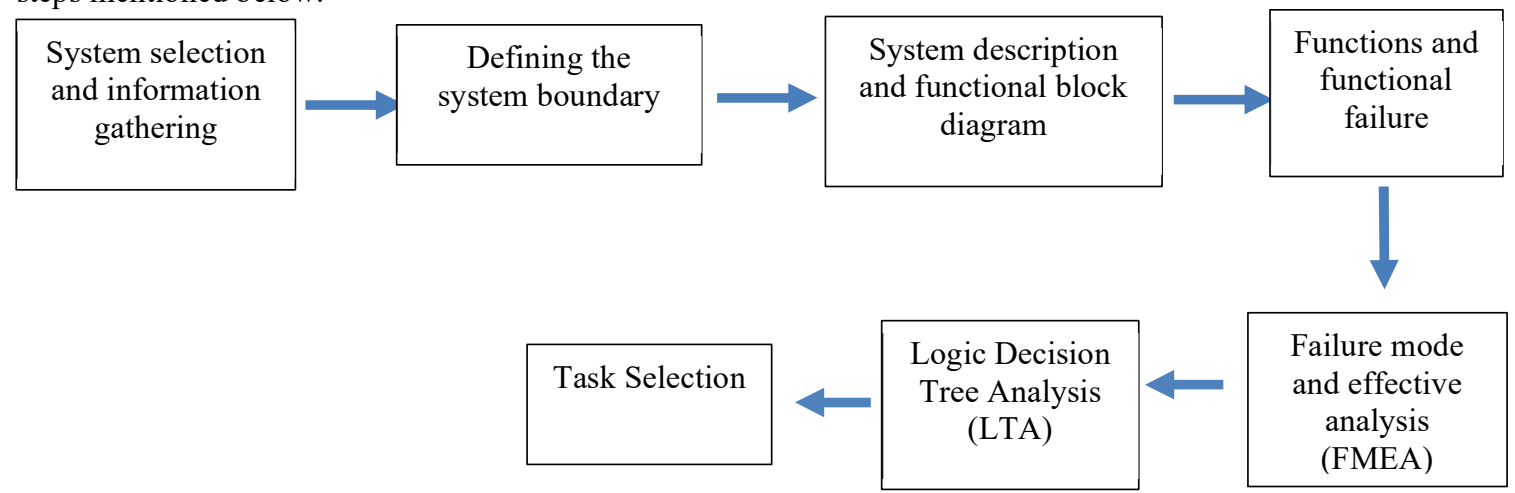

Figure 1. Steps for the RCM Methodology

System selection and data collection.

To select the line of study, the scheduled maintenance records for 2020 and the corrective maintenance records for February 2021 were analyzed. From the information of the first study, we extracted the data of the three main equipment that occupy more time in preventive repair and from the second one we obtained information of the failures in the equipment.

Table 1: Preventive maintenance frequency.

\begin{tabular}{|c|c|c|c|}
\hline Machinery and Equipment & Estimated time & $\begin{array}{c}\text { Frequency per } \\
\text { year }\end{array}$ & Total time per year (hr) \\
\hline \multicolumn{4}{|c|}{ Line JUMBO 1} \\
\hline Jumbo 1 & 10 & 6 & 60 \\
\hline Bramalin Press PH-30 & 3 & 10 & 30 \\
\hline Cutter 1 and 2 & 4 & 5 & 20 \\
\hline \multicolumn{4}{|c|}{ Line A } \\
\hline Guillotine LA & 2 & 52 & 104 \\
\hline Furnace & 10 & 8 & 80 \\
\hline Airplay & 4 & 7 & 28 \\
\hline \multicolumn{4}{|c|}{ Line B } \\
\hline Punching machine & 2 & 50 & 100 \\
\hline Furnace B & 5 & 10 & 50 \\
\hline cutters & 1 & 48 & 48 \\
\hline \multicolumn{4}{|c|}{ Line C } \\
\hline Guillotine LC & 2 & 52 & 104 \\
\hline Furnace & 10 & 6 & 60 \\
\hline Silo C & 9 & 6 & 54 \\
\hline \multicolumn{4}{|c|}{ Line JUMBO 2} \\
\hline Jumbo 2 & 10 & 5 & 50 \\
\hline Dust collector & 5 & 6 & 30 \\
\hline Silo & 4 & 4 & 16 \\
\hline
\end{tabular}


Table 2: Corrective maintenance. (February, 2021)

\begin{tabular}{|c|c|c|}
\hline Unit & Failures per month & Time (Hours) \\
\hline \multicolumn{3}{|c|}{ Line A } \\
\hline Flexiloft & 7 & $03: 50$ \\
\hline Furnace & 7 & 02:00 \\
\hline Mix & 6 & 03:00 \\
\hline Airlay & 10 & $05: 20$ \\
\hline Cotton threads opener & 3 & $01: 30$ \\
\hline Receiver & 6 & $01: 50$ \\
\hline \multicolumn{3}{|c|}{ Line B } \\
\hline DOA & 11 & 07:38 \\
\hline Side cutter & 1 & $00: 25$ \\
\hline Furnace & 2 & $01: 15$ \\
\hline Receiver & 4 & $02: 10$ \\
\hline Opener & 1 & $00: 15$ \\
\hline Punching machine & 1 & $01: 15$ \\
\hline Glue & 1 & $00: 55$ \\
\hline \multicolumn{3}{|c|}{ Line $\mathrm{C}$} \\
\hline Flexiloft & 3 & $01: 40$ \\
\hline Receiver & 6 & $01: 50$ \\
\hline Mix & 12 & $09: 15$ \\
\hline Cotton threads opener & 2 & $01: 15$ \\
\hline Silo & 4 & $05: 35$ \\
\hline Furnace & 2 & $00: 40$ \\
\hline Airlay & 2 & $03: 20$ \\
\hline Piker (horizontal band) & 1 & $00: 55$ \\
\hline
\end{tabular}

Based on the analysis of the information, it was determined that Line $\mathrm{C}$ receives more preventive maintenance and has a frequency of 12 failures per month, making it the line with the most failures. It should be noted that the failures that stand out are mechanical, electrical and process failures.

Definition of the system boundary

The function of line $\mathrm{C}$ is to manufacture nonwoven fabrics, it is composed of various equipment such as openers, airlay flexiloft, furnace, cutters, guillotines, dust collectors, silo, piker and belt. For this project, the analysis was limited to the piker blending system.

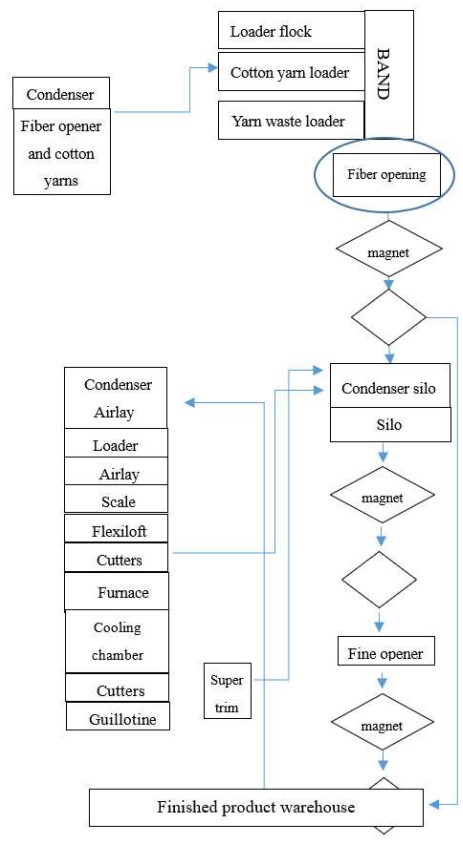

Figure 2. The production system 


\section{Fiber blender}

Piker mix, (figure 3) is an equipment that combines the flock and the yarn strands homogeneously and at the same time eliminates dust from the flakes coming from the loader lines. It consists of rollers, mixer, silos and a lower screen that simultaneously recovers fibers from the silo.

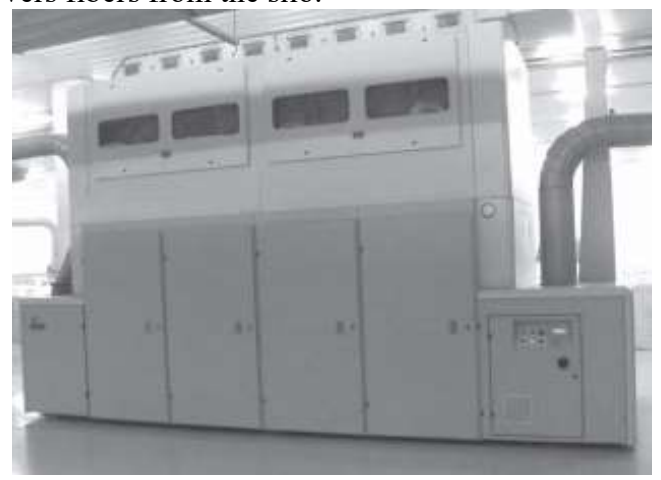

Figure 3: Piker Mix

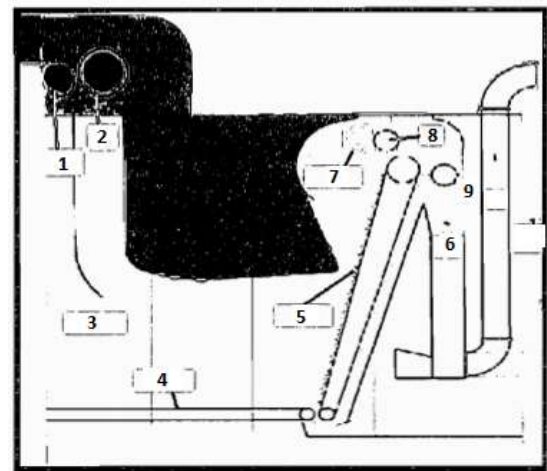

Figure 4: Main mixer components

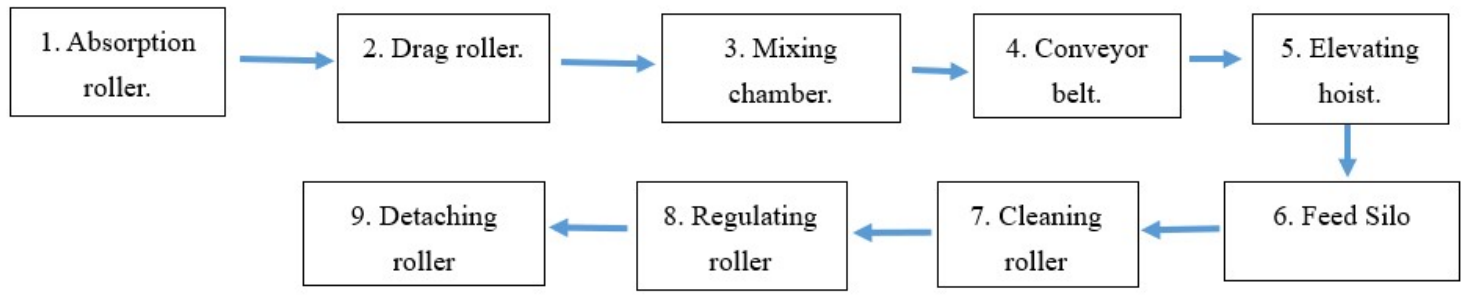

Figure 5: Description of mixer components

\section{Function and functional failure.}

Although, RCM is still not applied in many process plants, due to the lack of adequate methodology and tools, for this case, a general RCM analysis model suitable for the type of process and subsystems where the functional failures and failure modes that fall on critical components are exposed is proposed. (Vishnu \& Regikumar, 2016). The model is suitable for all types of process plants with any number of components and for any configuration. By evaluating the effects, it allows to increase the availability of the equipment. This section answers the question: How can they fail, can they fail in a total or partial way?. It can be seen in Table 3. 
Table 3. Information sheet

\begin{tabular}{|c|c|c|c|c|c|c|c|}
\hline \multicolumn{8}{|c|}{ RCM INFORMATION SHEET, SYSTEM: LINE C } \\
\hline & $\begin{array}{l}\text { RCM } \\
\text { formation } \\
\text { Sheet }\end{array}$ & \multicolumn{4}{|c|}{ System/ Active: Line C } & \multicolumn{2}{|l|}{ Facilitator: } \\
\hline & $\begin{array}{l}\text { ibras de } \\
\text { lima S.A } \\
\text { de C.V. }\end{array}$ & \multicolumn{4}{|c|}{ Subsystem/component: Fiber blender } & \multicolumn{2}{|l|}{ Collaborator: } \\
\hline \multicolumn{2}{|c|}{ Function } & \multicolumn{2}{|c|}{$\begin{array}{l}\text { Functional } \\
\text { failure }\end{array}$} & \multicolumn{2}{|c|}{ Failure Mode } & Cause & Effect \\
\hline \multirow{4}{*}{1} & \multirow{4}{*}{$\begin{array}{l}\text { Raw } \\
\text { material } \\
\text { input to } \\
\text { the } \\
\text { system }\end{array}$} & \multirow{4}{*}{$\mathrm{A}$} & \multirow{4}{*}{$\begin{array}{l}\text { Failure of } \\
\text { the } \\
\text { absorption } \\
\text { roller and } \\
\text { the drag } \\
\text { roller }\end{array}$} & \multirow[t]{2}{*}{1} & \multirow[t]{2}{*}{ Slow operation. } & Metal-to-metal contact. & $\begin{array}{l}\text { Raw material enters } \\
\text { slowly so production } \\
\text { yield decreases. } \\
\end{array}$ \\
\hline & & & & & & Thin lubricant film. & Failures due to wear. \\
\hline & & & & 2 & Poor operation. & $\begin{array}{l}\text { Repeated stresses on the gear } \\
\text { surface. }\end{array}$ & Surface fatigue. \\
\hline & & & & 3 & Difficulty in operation. & Tooth stress overload beyond limit. & Tooth breakage. \\
\hline \multirow{15}{*}{2} & \multirow{15}{*}{$\begin{array}{l}\text { Fiber } \\
\text { blends }\end{array}$} & \multirow{2}{*}{$\mathrm{A}$} & \multirow{2}{*}{$\begin{array}{l}\text { Failure in } \\
\text { the mixing } \\
\text { chamber. }\end{array}$} & 1 & Slow operation. & $\begin{array}{l}\text { Problems with the internal } \\
\text { components of the mixing chamber }\end{array}$ & $\begin{array}{l}\text { The process stops or } \\
\text { slows down. }\end{array}$ \\
\hline & & & & 2 & Camera does not work. & Insufficient power provided. & $\begin{array}{l}\text { The operation cannot } \\
\text { be performed. }\end{array}$ \\
\hline & & \multirow{7}{*}{ B } & \multirow{7}{*}{$\begin{array}{l}\text { Conveyor } \\
\text { belt failure. }\end{array}$} & \multirow{3}{*}{1} & \multirow{3}{*}{ Material spills } & $\begin{array}{l}\text { Grooves on each side of the belt due } \\
\text { to pressure generated by the side } \\
\text { guards. }\end{array}$ & Provisioning damage. \\
\hline & & & & & & $\begin{array}{l}\text { Belt overtension or severe trough } \\
\text { angle. }\end{array}$ & Belt concave. \\
\hline & & & & & & Small diameter of structure pulleys & $\begin{array}{l}\text { Separation of belt } \\
\text { layers }\end{array}$ \\
\hline & & & & \multirow{4}{*}{2} & \multirow{4}{*}{$\begin{array}{l}\text { Accumulation of } \\
\text { material }\end{array}$} & Twisted belt loads. & Band not aligned \\
\hline & & & & & & Belt not aligned. & Splice failure \\
\hline & & & & & & $\begin{array}{l}\text { Due to belt manufacturing or } \\
\text { incorrect belt storage }\end{array}$ & $\begin{array}{l}\text { Failure in longitudinal } \\
\text { bending }\end{array}$ \\
\hline & & & & & & $\begin{array}{l}\text { Difference between belt and pulley } \\
\text { diameters. }\end{array}$ & Coating cracks \\
\hline & & \multirow{4}{*}{$\mathrm{C}$} & \multirow{4}{*}{$\begin{array}{l}\text { Failure in } \\
\text { the elevator } \\
\text { screen. }\end{array}$} & \multirow[t]{2}{*}{1} & \multirow{2}{*}{$\begin{array}{l}\text { Material is not } \\
\text { conveyed to the feed } \\
\text { silo }\end{array}$} & Very high chain speed. & $\begin{array}{l}\text { Breakage of pins, } \\
\text { bushings or rollers }\end{array}$ \\
\hline & & & & & & Excessive impact loads. & Breakage of teeth. \\
\hline & & & & \multirow{2}{*}{2} & \multirow{2}{*}{ Slow transfer } & Stiff chain. & Misaligned wheels \\
\hline & & & & & & $\begin{array}{l}\text { Lateral wear of plates on chain links } \\
\text { and sprockets. }\end{array}$ & Chain breakage \\
\hline & & \multirow{2}{*}{$\mathrm{D}$} & \multirow{2}{*}{$\begin{array}{l}\text { Failure in } \\
\text { the feeding } \\
\text { silo. }\end{array}$} & 1 & Incorrect operation of & Failure of insulators & Internal short circuits. \\
\hline & & & & 1 & the light sensor. & Dirt due to metal particles & Sensor slows down \\
\hline & $\begin{array}{l}\text { Return } \\
\text { the fiber } \\
\text { to }\end{array}$ & $\mathrm{A}$ & $\begin{array}{l}\text { Clogging } \\
\text { in the } \\
\text { cleaner and }\end{array}$ & 1 & Slow roller operation. & $\begin{array}{l}\text { Problems with the starter pulley } \\
\text { system and belt. }\end{array}$ & $\begin{array}{l}\text { The fibers are not } \\
\text { removed from the } \\
\text { regulating roller and } \\
\text { the elevator web. }\end{array}$ \\
\hline 3 & $\begin{array}{l}\text { continue } \\
\text { the }\end{array}$ & & stripper & 2 & Roller does not start.. & Engine problems. & The process stops. \\
\hline & $\begin{array}{l}\text { mixing } \\
\text { process. }\end{array}$ & B & $\begin{array}{l}\text { Flock } \\
\text { adhesion }\end{array}$ & 1 & $\begin{array}{l}\text { Flock clogging in the } \\
\text { system. }\end{array}$ & Roller movement is slow. & $\begin{array}{l}\text { The roller stops and } \\
\text { there is a shortage of } \\
\text { flock. }\end{array}$ \\
\hline
\end{tabular}

E. Failure Mode and Effect Analysis (FMEA)

The FMEA method allows the analysis of potential errors a priori. Research in this field aims to mitigate this risk 
with combinations of case-specific approaches, identifying functional failures and failure modes (Peter, Aldon, Schupp, \& Salzwedel, 2021). In its analysis, the aim is to avoid critical errors, proposing actions oriented to solve them. The FMEA uses the Risk Priority Number (RPN) technique to determine risk impact (severity), risk likelihood (occurrence), and risk opportunities (detection). The RPN value is obtained by multiplying the value of the three parameters. Risks with the highest values are considered important and should receive a high priority compared to risks with low RPN values (Privadi \& Fadilah, 2020). This section answers the question "What causes the failure"?, an analysis is performed using the FMEA methodology as shown in Table 4. Values are assigned to the cases of severity, occurrence and detection consisting of a weighting from 1 to 10 to define the severity of the effect and the occurrence of the causes of failure being 1 minimum and 10 very high, in the case of the controls their current detection was evaluated using a weighting from 1 to 10 being the number 1 high and 10 minimum. (Mulet, Carlos, Chulvi, Ramos, \& Bovea, 2011)

Table 4: FMEA

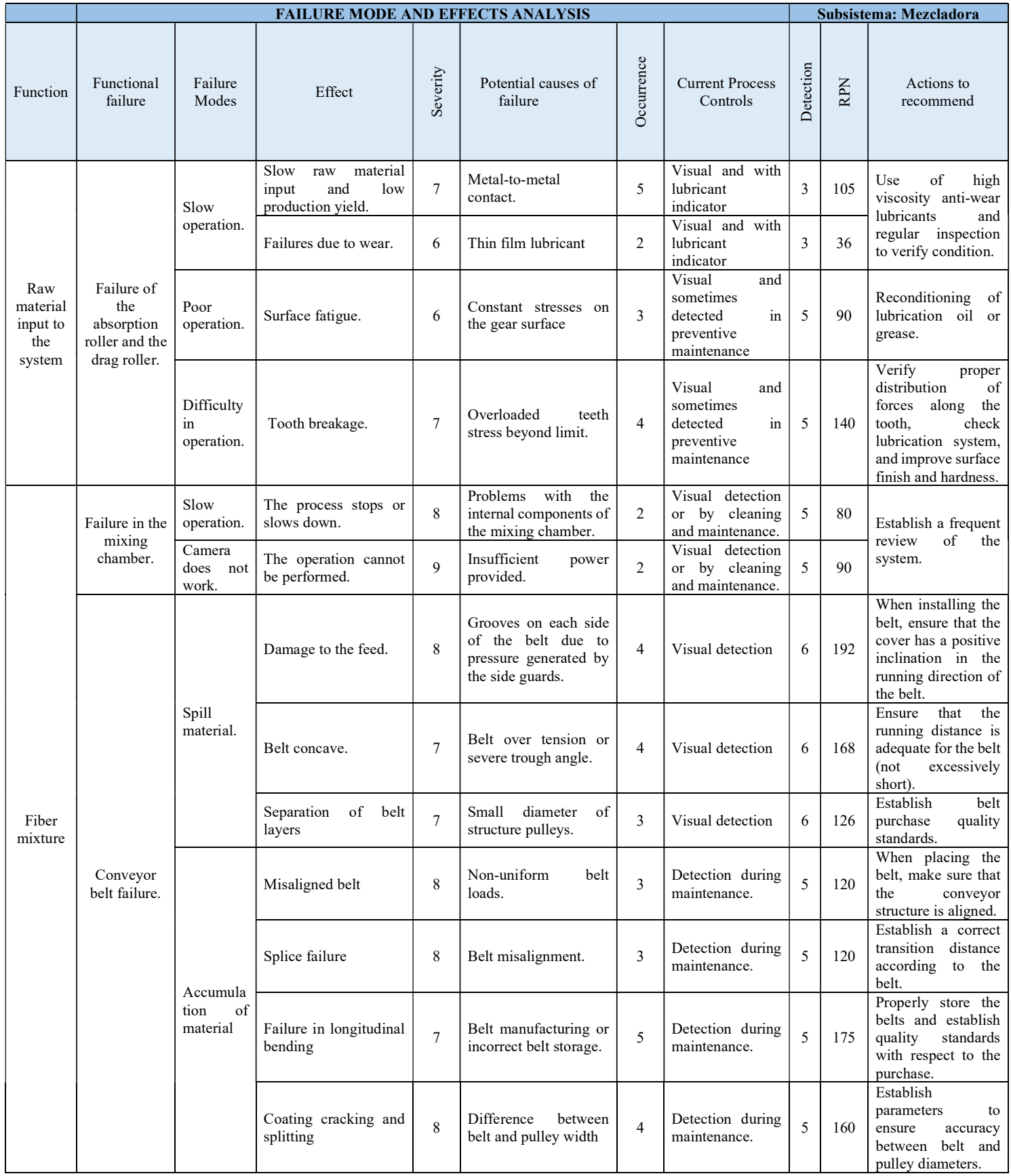




\begin{tabular}{|c|c|c|c|c|c|c|c|c|c|c|}
\hline & \multirow{4}{*}{$\begin{array}{l}\text { Elevating } \\
\text { hoist failure. }\end{array}$} & \multirow{2}{*}{$\begin{array}{l}\text { The } \\
\text { material is } \\
\text { not } \\
\text { transferred } \\
\text { to the feed } \\
\text { silo. }\end{array}$} & $\begin{array}{l}\text { Breakage of pins, } \\
\text { bushings or rollers. }\end{array}$ & 8 & High speed in chain & 4 & $\begin{array}{l}\text { Visual detection } \\
\text { and during } \\
\text { maintenance }\end{array}$ & 5 & 160 & $\begin{array}{l}\text { Develop a detection } \\
\text { plan that monitors } \\
\text { the tension in the } \\
\text { chain drives, } \\
\text { replacing it if it is } \\
\text { greater than } 3 \% \text { and } \\
\text { adequate } \\
\text { lubrication. }\end{array}$ \\
\hline & & & $\begin{array}{l}\text { Breakage of the gear } \\
\text { teeth }\end{array}$ & 7 & $\begin{array}{l}\text { Excessive impact } \\
\text { loads. }\end{array}$ & 3 & $\begin{array}{l}\text { Detection during } \\
\text { maintenance. }\end{array}$ & 5 & 105 & $\begin{array}{lrr}\text { Carry } & \text { out } & \text { an } \\
\text { adequate } & \text { cleaning } \\
\text { and } & \text { greasing } \\
\text { program } & \text { for the } \\
\text { chain. } & & \\
\text { chain. } & \end{array}$ \\
\hline & & $\begin{array}{l}\text { Slow } \\
\text { transfer }\end{array}$ & Rigid chain. & 7 & $\begin{array}{l}\text { Misaligned guide } \\
\text { rollers }\end{array}$ & 5 & $\begin{array}{l}\text { Visual detection } \\
\text { and during } \\
\text { maintenance }\end{array}$ & 5 & 175 & $\begin{array}{l}\text { Establish a frequent } \\
\text { cleaning schedule, } \\
\text { as well as proper } \\
\text { maintenance and } \\
\text { lubrication. }\end{array}$ \\
\hline & & & Chain breakage & 7 & $\begin{array}{l}\text { Lateral wear of the } \\
\text { plates on the chain } \\
\text { links and guide teeth. }\end{array}$ & 4 & Visual detection & 6 & 168 & $\begin{array}{l}\text { Periodically check } \\
\text { chain sprocket } \\
\text { alignment. }\end{array}$ \\
\hline & Failure in the & $\begin{array}{l}\text { The light } \\
\text { sensor is not }\end{array}$ & $\begin{array}{l}\text { Internal short } \\
\text { circuits. }\end{array}$ & 8 & Failure of insulators & 3 & $\begin{array}{l}\text { Visual detection } \\
\text { during } \\
\text { maintenance. }\end{array}$ & 5 & 120 & Frequent sensor \\
\hline & feeding silo. & $\begin{array}{l}\text { working } \\
\text { properly. }\end{array}$ & $\begin{array}{l}\text { Delayed sensor } \\
\text { operation. }\end{array}$ & 8 & $\begin{array}{l}\text { Dirt due to metal } \\
\text { particles }\end{array}$ & 7 & $\begin{array}{l}\text { Visual detection } \\
\text { or by cleaning } \\
\text { and maintenance. }\end{array}$ & 5 & 280 & check. \\
\hline $\begin{array}{l}\text { Return } \\
\text { the fiber }\end{array}$ & Poor roller & $\begin{array}{l}\text { Roller } \\
\text { blockage }\end{array}$ & $\begin{array}{l}\text { Fibers are not } \\
\text { removed from the } \\
\text { regulating roller or } \\
\text { in the fiber elevator. }\end{array}$ & 8 & $\begin{array}{l}\text { Problems with the } \\
\text { starter pulley and belt } \\
\text { system. }\end{array}$ & 4 & Visual detection. & 6 & 192 & Conditioning of a \\
\hline $\begin{array}{l}\text { to } \\
\text { continue } \\
\text { the }\end{array}$ & & $\begin{array}{l}\text { Roller does } \\
\text { not rotate }\end{array}$ & The process stops. & 8 & Engine stalled & 3 & $\begin{array}{l}\text { Visual detection } \\
\text { during } \\
\text { maintenance. }\end{array}$ & 5 & 120 & \\
\hline $\begin{array}{l}\text { mixing } \\
\text { process. }\end{array}$ & $\begin{array}{l}\text { Adhesion of } \\
\text { flock }\end{array}$ & $\begin{array}{l}\text { Flock } \\
\text { blockage in } \\
\text { the system. }\end{array}$ & $\begin{array}{l}\text { Roller stalls and } \\
\text { does not deliver } \\
\text { adequate flocking } \\
\text { level }\end{array}$ & 7 & $\begin{array}{l}\text { The movement of the } \\
\text { regulating roller is } \\
\text { slow. }\end{array}$ & 3 & Light sensor & 3 & 63 & \\
\hline
\end{tabular}

The FMEA method allows the analysis of potential errors a priori. Research in this field aims to mitigate this risk with combinations of case-specific approaches, identifying functional failures and failure modes. In its analysis, the aim is to avoid critical errors, proposing actions oriented to solve them.

\section{F. Decision tree analysis.}

In order to determine the appropriate type of maintenance with respect to the failure mode, the tasks to be carried out per system were defined; it should be added that the failures detected are only mechanical.

\section{G. Task selection.}

Finally, the tasks are shown below.

Table 5. Task selection

\begin{tabular}{|c|c|c|c|}
\hline \multicolumn{4}{|c|}{ PREVENTIVE MAINTENANCE, SYSTEM: LINE C } \\
\hline & System/ Active: Line C & \multicolumn{2}{|c|}{ Facilitator: } \\
\hline $\begin{array}{l}\text { Fibras de colima S.A } \\
\text { de C.V. }\end{array}$ & Subsystem/component: Fiber blender & \multicolumn{2}{|c|}{ Collaborator: } \\
\hline Component & Activity & Priority & Categories \\
\hline \multirow{3}{*}{ Rollers } & Use of high viscosity anti-wear lubricants. & High & Mechanical \\
\hline & $\begin{array}{l}\text { Verify proper distribution of forces along the tooth, improve } \\
\text { surface finish and hardness. }\end{array}$ & Medium & Mechanical \\
\hline & Regular inspection to verify condition. & Medium & Mechanical \\
\hline Mixing Chamber & Frequent system inspection. & Medium & Mechanical \\
\hline \multirow{6}{*}{ Conveyor belt } & $\begin{array}{l}\text { When installing the belt, ensure that the cover has a positive } \\
\text { inclination in the running direction of the belt. }\end{array}$ & Medium & Mechanical \\
\hline & $\begin{array}{l}\text { Ensure that the running distance is adequate for the belt (not } \\
\text { excessively short). }\end{array}$ & Medium & Mechanical \\
\hline & Establish belt purchase quality standards. & Medium & Mechanical \\
\hline & $\begin{array}{l}\text { When placing the belt, make sure that the conveyor structure is } \\
\text { aligned. }\end{array}$ & Medium & Mechanical \\
\hline & Establish a correct transition distance according to the belt. & Medium & Mechanical \\
\hline & $\begin{array}{l}\text { Properly store the belts and establish quality standards with } \\
\text { respect to the purchase }\end{array}$ & Medium & Mechanical \\
\hline
\end{tabular}




\begin{tabular}{|c|l|l|l|}
\hline & $\begin{array}{l}\text { Establish parameters to ensure accuracy between belt and } \\
\text { pulley diameters. }\end{array}$ & Medium & Mechanical \\
\hline \multirow{5}{*}{ Fiber elevator } & $\begin{array}{l}\text { Carry out a plan to control the tensioning of chain drives, } \\
\text { replacing it if it is more than 3\%. }\end{array}$ & Medium & Mechanical \\
\cline { 2 - 4 } & $\begin{array}{l}\text { Establish frequent cleaning, as well as proper maintenance and } \\
\text { lubrication. }\end{array}$ & Medium & Mechanical \\
\cline { 2 - 4 } & Periodically check chain sprocket alignment. & Medium & Mechanical \\
\hline Feed Silo & Frequent sensor check. & Medium & Mechanical \\
\hline
\end{tabular}

\section{CONCLUSIONS}

The development of the RCM methodology allowed to establish an analysis of the production lines of the company Fibras de Colima S.A de C.V, where, in the first place, the system was selected based on data provided by the company, such as preventive maintenance during the year 2020 and corrective maintenance during the month of February of this year (2021), thus, the selected system was the Line C, specifically in the Mixer or fiber opener, where the functions and functional failures were determined. Thus, a failure mode and effect analysis was established, which consisted of developing a detailed study of the equipment function and determining the failure modes, the effect that this produces, the causes and the current process controls. This information makes it possible to establish the activities to be carried out to correct or reduce the inconsistencies.

In this way, the central objective of the project is fulfilled, which consisted in the analysis of the factory's equipment, applying the RCM and AMEF methodologies, in order to improve its operational performance. Likewise, the contributions of the present project, which are the activities resulting from the plan that aim to improve the current maintenance system.

The most relevant activities are the application of high speed anti-wear lubricants, as well as the verification of the system's rollers and gears, which are intended to reduce mechanical failures that result in system failures.

Future research work should be oriented towards the application of the Bathtub Curve methodology, evaluating the moment in which the equipment or machinery reaches a maximum rate, implementing actions and extending the mean time between failures (MTBF).

\section{References}

Afefy, I. (2010). Reliability-Centered Maintenance Methodology and Application: A Case Study. Scientific Research, 863-873.

Altaf, M. (2014). Study Reliability Centered Maintenance (RCM) of Rotating Equipment through Predictive Maintenance. 2nd International Conference on Research in Science, Engineering and Technology (ICRSET'2014), 216-221.

Aristizabal, E. T. (2015). Análisis del sector colchonero en latinoamérica. Armenia.

Command, N. S. (1983). Naval Sea Systems Command. Reliability-Centered Maintenance Handbook, 1-56.

Dominic, M. (2021). Optimization of condition-based maintenance strategy prediction for aging automotive industrial equipment using FMEA. International Conference on Industry 4.0 and Smart Manufacturing, 229238.

Ivester, A., \& y Neefus, J. (2012). Industria de Productos Textiles. En A. Ivester, \& J. y Neefus, Industria de Productos Textiles (págs. 2-30). México: ENCICLOPEDIA DE SALUD Y SEGURIDAD EN EL TRABAJO.

López, L. (1989). Nómadas y Sedentarios. CDMX: Instituto Nacional de Antropología e Historia.

Mulet, E., Carlos, M., Chulvi, V., Ramos, J., \& Bovea, D. (2011). Problemas resueltos de análisis de riesgos en instalaciones industriales. Castelló de la Plana, España: Publicacions de la Universitat Jaume I. Servei de Comunicació i Publicacions.

Pepper, D. (Noviembre de 2018). http://www.madehow.com/Volume-1/Mattress.html. Obtenido de http://www.madehow.com/Volume-1/Mattress.html

Peter, B., Aldon, T., Schupp, S., \& Salzwedel, J. (2021). Risk Management in Factory Planning - A Literature Review. 54th CIRP Conference on Manufacturing Systems, 1191-1196.

Privadi, A., \& Fadilah, N. (2020). The consistency analysis of failure mode and effect analysis (FMEA) in information technology risk assessment. Heliyon, 1-12.

Ramli, R., \& Nizam, M. N. (2012). Reliability Centered Maintenance in Schedule Improvement of Automotive Assembly Industry. American Journal of Applied Sciences, 1232-1236.

Rausand, M. (1998). Reliability Centered Maintenance. Reliability Engineering and System Safety, 121-132.

Toro, e. (s.f.).

Toro, E. (2015). ANÁLISIS DEL SECTOR COLCHONERO EN LATINOAMÉRICA. Armenia.

Vishnu, C., \& Regikumar, V. (2016). Reliability Based Maintenance Strategy Selection in Process Plants: A Case Study. Procedia Technology, 1080-1087. 